\title{
Documentation of Ceramic Vessels from an Early Caddo Period Feature at the Boxed Spring Site (41UR30) Site, Upshur County, Texas
}

Timothy K. Perttula

Heritage Research Center, Stephen F. Austin State University

Mark Walters

Heritage Research Center, Stephen F. Austin State University

Follow this and additional works at: https://scholarworks.sfasu.edu/ita

Part of the American Material Culture Commons, Archaeological Anthropology Commons, Environmental Studies Commons, Other American Studies Commons, Other Arts and Humanities Commons, Other History of Art, Architecture, and Archaeology Commons, and the United States History Commons

Tell us how this article helped you.

This Article is brought to you for free and open access by the Center for Regional Heritage Research at SFA ScholarWorks. It has been accepted for inclusion in Index of Texas Archaeology: Open Access Gray Literature from the Lone Star State by an authorized editor of SFA ScholarWorks. For more information, please contact cdsscholarworks@sfasu.edu. 
Documentation of Ceramic Vessels from an Early Caddo Period Feature at the Boxed Spring Site (41UR30) Site, Upshur County, Texas

\section{Creative Commons License}

\section{(c) (1) (8)}

This work is licensed under a Creative Commons Attribution-NonCommercial 4.0 International License 


\title{
Documentation of Ceramic Vessels from an Early Caddo Period Feature at the Boxed Spring Site (41UR30) Site, Upshur County, Texas
}

\author{
Timothy K. Perttula and Mark Walters
}

\section{INTRODUCTION}

The Boxed Spring site (41UR30) is an ancestral Caddo mound center of apparent Early Caddo age (ca. A.D. 900-1200) on the Sabine River, situated on an upland landform a short distance upstream from the Sabine River's confluence with Big Sandy Creek (Figure 1). The site is located in the modern East Texas Pineywoods, and is estimated to cover approximately 48 acres of a large and prominent upland ridge projection.

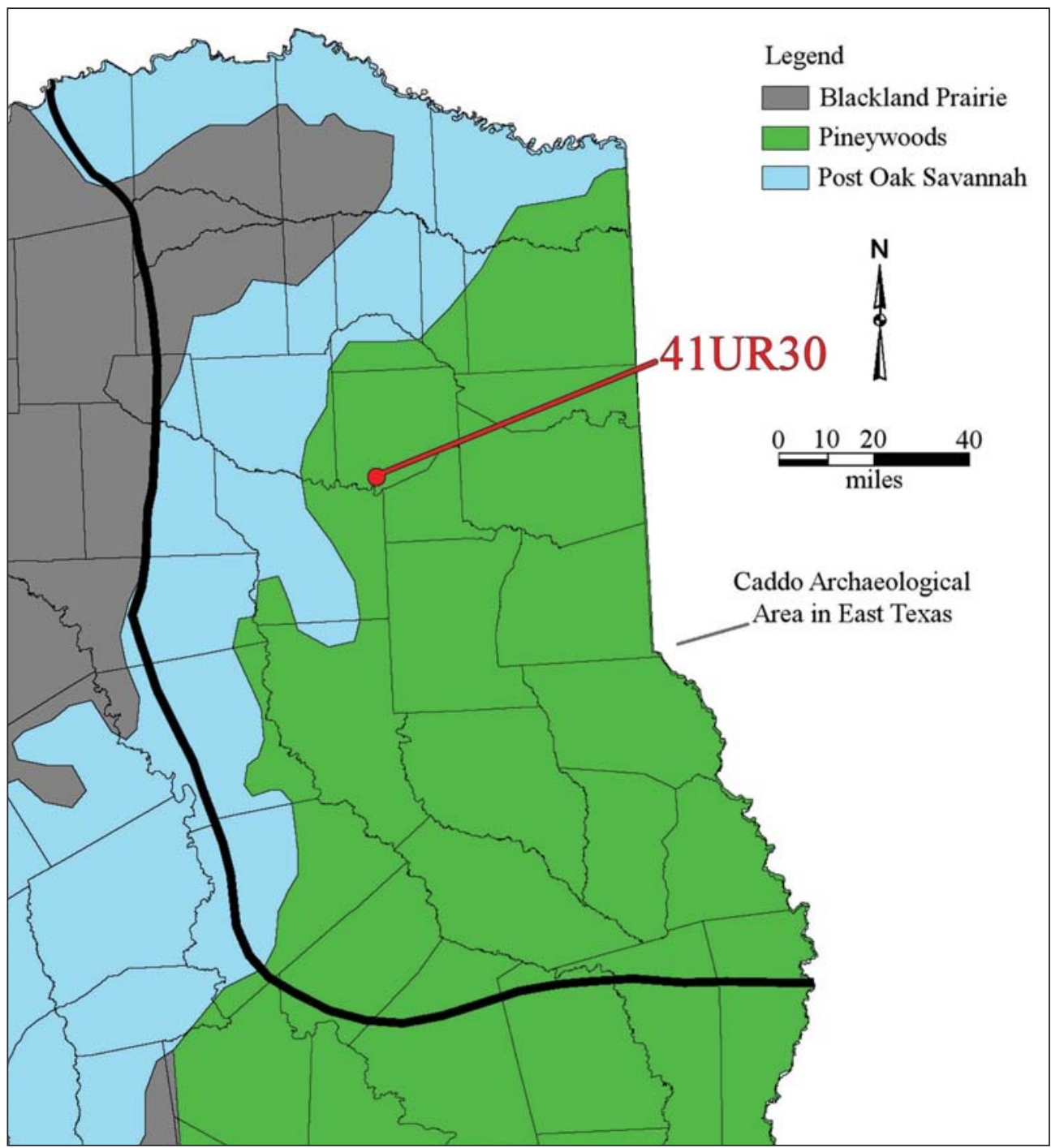

Figure 1. Location of the Boxed Spring site in East Texas. 
There are four mounds (A-D) at the site arranged around an open area or central plaza, and there were several habitation areas to the north and south of the sets of mounds (Figure 2). Mounds C and D are low structural mounds (i.e., mounds built over dismantled and destroyed house structures) with prepared clay floors at the southeastern and southwestern ends of the open area or plaza. Mound C was 10.7 x $13.4 \mathrm{~m}$ in size. Mound D had a $45 \mathrm{~cm}$ thick zone of sand as mound fill over a prepared clay floor to a structure. Mound A was a burial mound about $12 \times 8 \times 2 \mathrm{~m}$ in length, width, and height at the northwestern plaza edge, and Mound B was a flat-topped mound of unknown function at the northeastern end of the plaza (Perttula 2011).

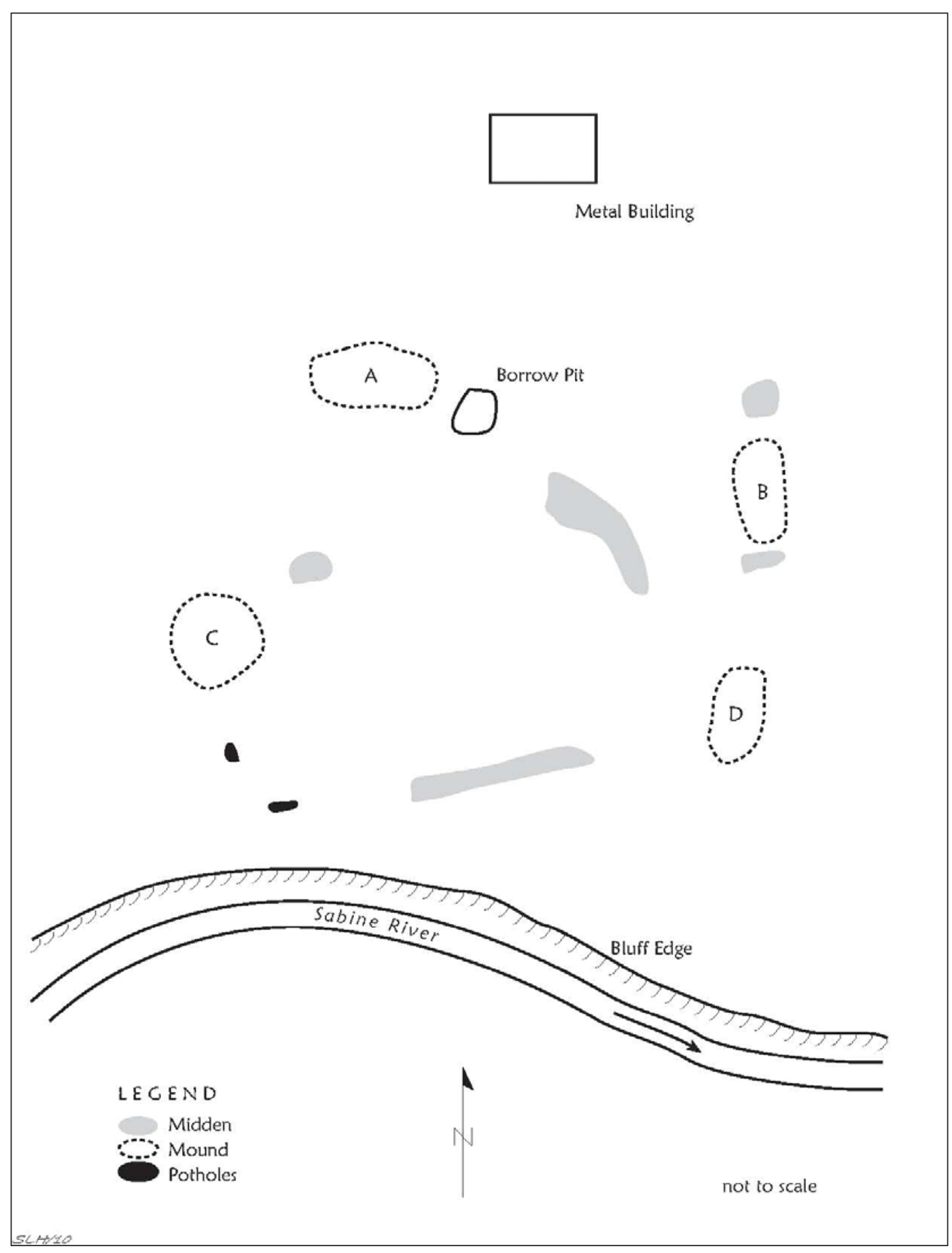

Figure 2. Map of the Boxed Spring site, ca. 1982. 


\section{Context of the Ceramic Vessels}

Excavations in Mound A in 1962 by Sam Whiteside uncovered a large central tomb feature. When the mound fill (a gray sandy loam) was removed with a tractor blade, a rectangular patch of brown clay was exposed just below the mound surface, followed by a poorly preserved burial (Burial 1) about $0.9 \mathrm{~m}$ bs in the central part of the mound. This feature consisted of a charcoal stain and fragments of human bone, some of which were charred (suggesting they were cremated bone), as well as a human molar. A large celt made from a Ouachita Mountains lithic raw material was recovered while troweling the burial feature (Figure 3), as well as a mano (Perttula and Wilson 2000:39 and Figures 6 and 11).

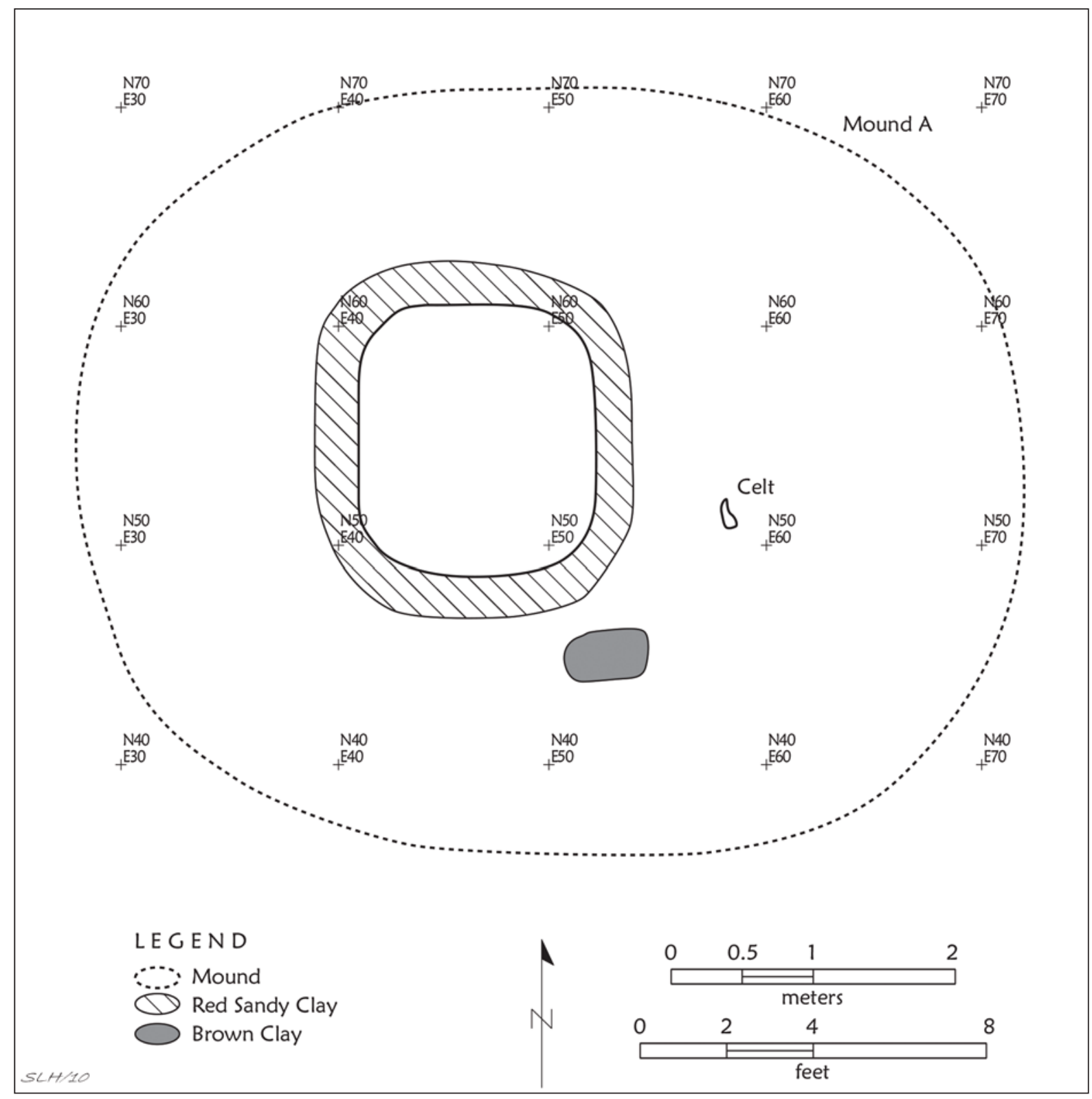

Figure 3. Mound A excavations and location of Burial 2 pit. 
Continued excavations eventually exposed a large circular ring or berm of clay near the base of the mound (see Figure 3), beginning about 0.9-1.2 m below the surface. This ring of red sandy clay was $0.6 \mathrm{~m}$ in width and $16 \mathrm{~cm}$ thick, and marked a berm around a large clay- and sand-filled pit. The top of the berm was between $0.6-1.2 \mathrm{~m}$ below the top of the mound. The pit was $3.8 \times 4.1 \mathrm{~m}$ at the top and narrowed to 3.2 $\mathrm{x} 3.5 \mathrm{~m}$ at the bottom, and had rounded corners and slightly sloping walls. The upper and central portions of the pit had a white sandy fill, with the remainder of the fill and berm grading from a red sandy clay to a very dense red clay just above the floor. The pit floor was covered with a $2.5-5 \mathrm{~cm}$ thick lens of bluish-gray clay (Figure 4), probably obtained by the Caddo from Pleistocene alluvial deposits along the Sabine River.

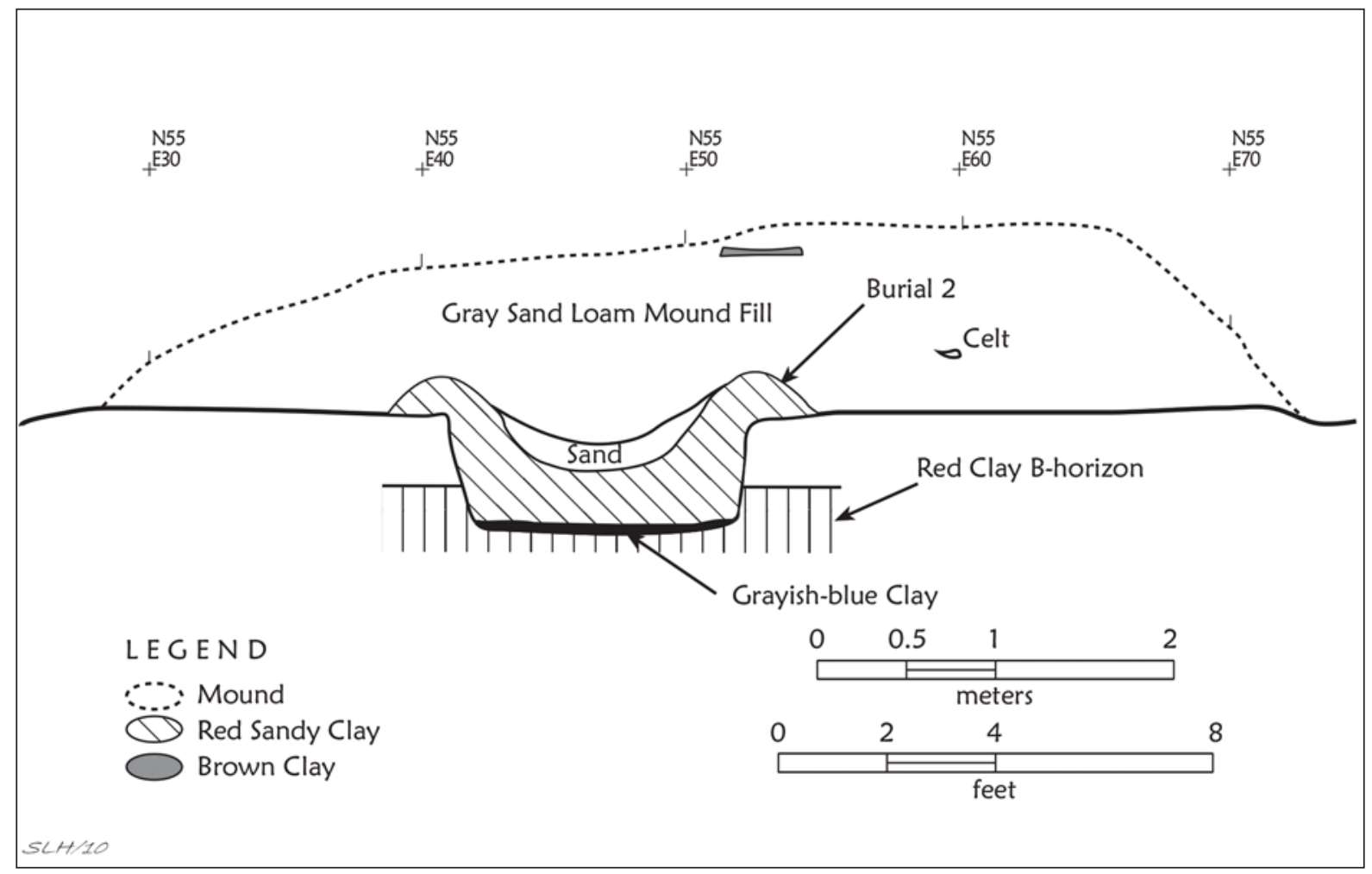

Figure 4. N55 profile in Mound A, showing Burial 2 pit, the position of the celt associated with Burial 1, and a patch of brown clay near the surface of the mound.

The Burial 2 pit feature at Boxed Springs had three sets of tooth enamel along the eastern side of the pit, but no other human remains were preserved in the feature (Figure 5). The broad spacing of the sets of tooth enamel suggests that the pit contained the bodies of three individuals that were laid out east-west, with the head facing west. The majority of the funerary objects placed on the floor of the burial pit were along the north side of the feature, north of the third set of tooth enamel, although three of the clusters of arrow points were in the central and southern parts of the feature, and one ceramic vessel (Vessel 5, a plain carinated bowl) was near the eastern pit wall (Figure 5).

Funerary objects placed in Burial 2 to accompany these three Caddo individuals on their journey to the afterlife included two large chipped stone bifaces made from non-local cherts, five ground stone celts, two polished stones, a ferruginous sandstone tool (possibly a saw), four clusters of arrow points, and eight ceramic vessels (V.1 to V.8) (Perttula and Wilson 2000:Figures 9-19). The arrow point clusters together included 100 points, mainly of the Alba type, made from both local quartzite and cherts as well as from other cherts from Ouachita Mountains or Red River gravel sources. Vessels 1 and 2 are plain bottles, Vessel 5 is a plain carinated bowl, and Vessels 6-8 are plain beakers. Vessel 4 is a small Spiro Engraved beaker. Vessel 3 is a $13 \mathrm{~cm}$ tall everted rim jar with a pinched ridge-decorated body and a zoned incised-circular punctated decoration on the rim. 


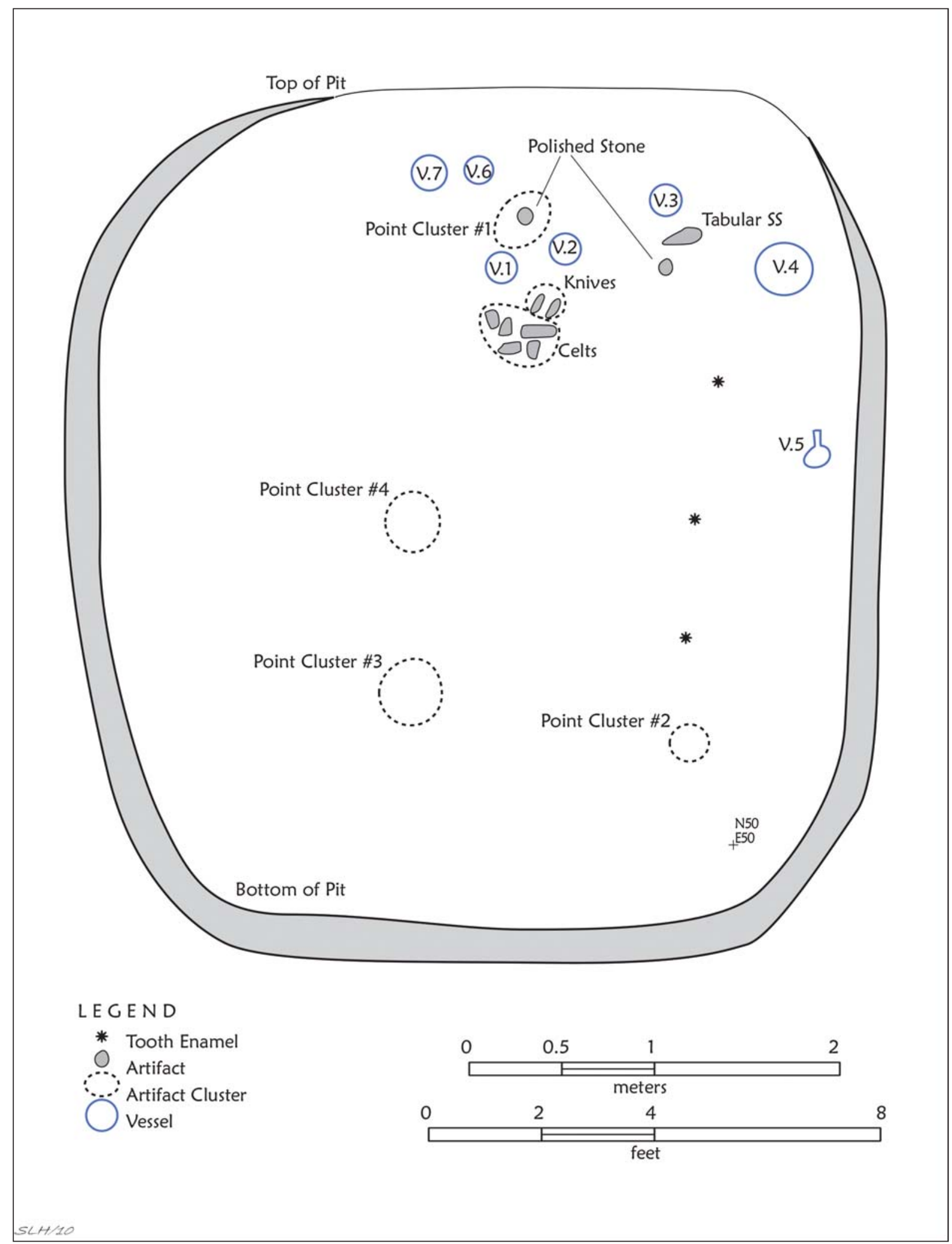

Figure 5. Burial 2 pit and the location of tooth enamel and associated funerary objects. V.1-V.7 are seven pottery vessels. 
These vessels and other funerary offerings from Burial 2 at the Boxed Spring site were donated to the Texas Archeological Research Laboratory at The University of Texas at Austin (TARL) in January 1986 by

Sam Whiteside, the excavator of the burial feature. We were able to formally document the eight vessels at TARL in September 2014.

\section{Ceramic Vessels}

SITE NAME OR SITE NUMBER: Boxed Spring

VESSEL NO.: 1-1

VESSEL FORM: Bottle with a globular body and a tapering neck $(10.7 \mathrm{~cm}$ in height)

NON-PLASTICS AND PASTE: grog

RIM AND LIP FORM: Direct rim and rounded lip

CORE COLOR: $\mathrm{G}$ (fired in a reducing environment and cooled in the open air)

INTERIOR SURFACE COLOR: grayish-brown

EXTERIOR SURFACE COLOR: yellowish-brown; fire clouds on the rim, body, and the base

WALL THICKNESS (IN MM): neck, $4.5 \mathrm{~mm}$; body, $5.6 \mathrm{~mm}$

INTERIOR SURFACE TREATMENT: none

EXTERIOR SURFACE TREATMENT: smoothed

HEIGHT (IN CM): 23.5

ORIFICE DIAMETER (IN CM): 4.1

DIAMETER AT BOTTOM OF RIM OR NECK (IN CM): 6.0; maximum body diameter is $16.3 \mathrm{~cm}$

BASE DIAMETER (IN CM) AND SHAPE OF BASE: N/A; circular and rounded

ESTIMATED VOLUME (IN LITERS): 0.38 liters

DECORATION (INCLUDING MOTIF AND ELEMENTS WHEN APPARENT): Plain

PIGMENT USE AND LOCATION ON VESSEL: None

TYPE AND VARIETY (IF KNOWN): Unidentified plain ware

SITE NAME OR SITE NUMBER: Boxed Spring

VESSEL NO.: 1-2

VESSEL FORM: Bottle with a globular body and a tapering neck 
NON-PLASTICS AND PASTE: grog

RIM AND LIP FORM: Direct rim and rounded lip

CORE COLOR: $\mathrm{G}$ (fired in a reducing environment and cooled in the open air)

INTERIOR SURFACE COLOR: grayish-brown

EXTERIOR SURFACE COLOR: dark yellowish-brown; fire clouds on the neck and body

WALL THICKNESS (IN MM): neck, $3.8 \mathrm{~mm}$; body, $4.4 \mathrm{~mm}$

INTERIOR SURFACE TREATMENT: none

EXTERIOR SURFACE TREATMENT: burnished

HEIGHT (IN CM): 18.5

ORIFICE DIAMETER (IN CM): 3.3

DIAMETER AT BOTTOM OF RIM OR NECK (IN CM): 6.4; maximum body diameter is $13.2 \mathrm{~cm}$

BASE DIAMETER (IN CM) AND SHAPE OF BASE: 7.3; circular and rounded

ESTIMATED VOLUME (IN LITERS): 0.25

DECORATION (INCLUDING MOTIF AND ELEMENTS WHEN APPARENT): Plain

PIGMENT USE AND LOCATION ON VESSEL: None

TYPE AND VARIETY (IF KNOWN): Unidentified plain ware

SITE NAME OR SITE NUMBER: Boxed Spring

VESSEL NO.: 1-3

VESSEL FORM: Jar

NON-PLASTICS AND PASTE: grog

RIM AND LIP FORM: Everted rim and rounded lip

CORE COLOR: $\mathrm{G}$ (fired in a reducing environment and cooled in the open air)

INTERIOR SURFACE COLOR: dark grayish-brown; fire clouds on the rim and body

EXTERIOR SURFACE COLOR: dark reddish-brown; fire clouds on the rim and body

WALL THICKNESS (IN MM): rim, $6.2 \mathrm{~mm}$

INTERIOR SURFACE TREATMENT: smoothed 
EXTERIOR SURFACE TREATMENT: none

HEIGHT (IN CM): 13.0

ORIFICE DIAMETER (IN CM): 13.2

DIAMETER AT BOTTOM OF RIM OR NECK (IN CM): 12.7

BASE DIAMETER (IN CM) AND SHAPE OF BASE: 7.0; circular and flat

ESTIMATED VOLUME (IN LITERS): 1.0 liters

DECORATION (INCLUDING MOTIF AND ELEMENTS WHEN APPARENT): The rim has a series of 14 alternating incised triangles filled with rows of circular punctations (Figure 6). The vessel body has a continuous series of diagonal pinched ridges, as seen on Hollyknowe Pinched vessels.

PIGMENT USE AND LOCATION ON VESSEL: None

TYPE AND VARIETY (IF KNOWN): Unidentified utility ware

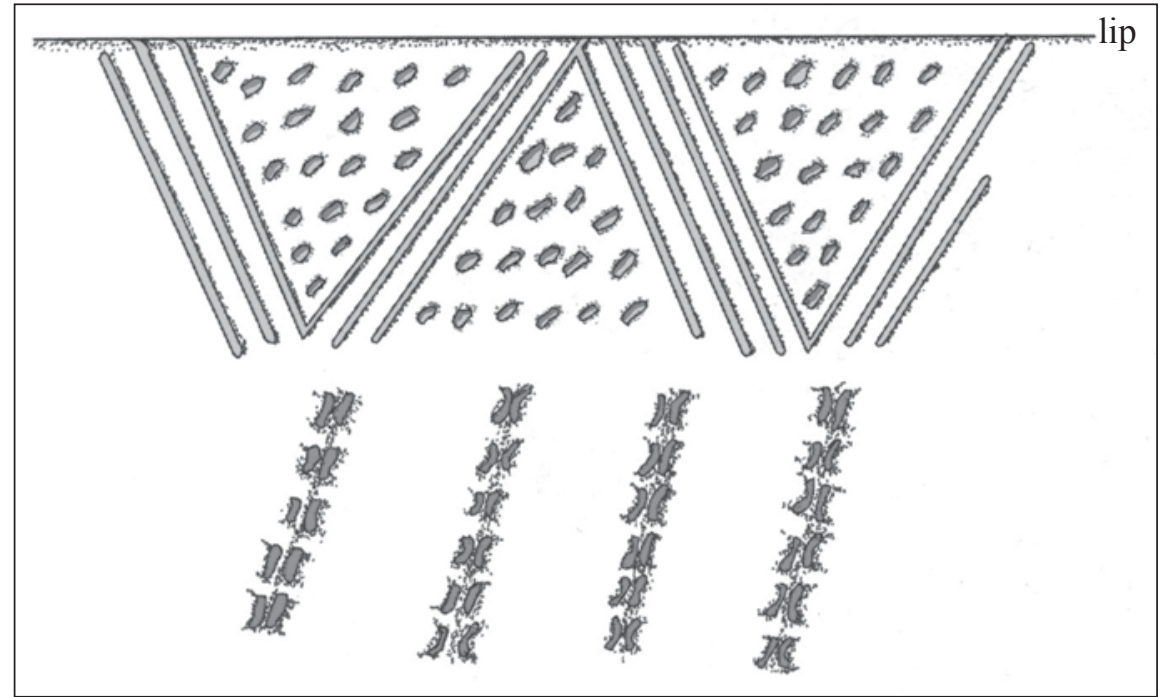

Figure 6. Incised-punctated-pinched jar from the Boxed Spring site.

SITE NAME OR SITE NUMBER: Boxed Spring

VESSEL NO.: 1-4

VESSEL FORM: Beaker

NON-PLASTICS AND PASTE: fine grog

RIM AND LIP FORM: Direct rim and rounded lip

CORE COLOR: $\mathrm{F}$ (fired in a reducing environment and cooled in the open air) 
INTERIOR SURFACE COLOR: reddish-brown; fire clouds on the rim, body, and the base

EXTERIOR SURFACE COLOR: reddish-brown; fire clouds on the body and base

WALL THICKNESS (IN MM): rim, 3.9 mm

INTERIOR SURFACE TREATMENT: smoothed

EXTERIOR SURFACE TREATMENT: burnished

HEIGHT (IN CM): 13.2

ORIFICE DIAMETER (IN CM): 8.6

DIAMETER AT BOTTOM OF RIM OR NECK (IN CM): N/A

BASE DIAMETER (IN CM) AND SHAPE OF BASE: 8.0; circular and convex

ESTIMATED VOLUME (IN LITERS): 0.68 liters

DECORATION (INCLUDING MOTIF AND ELEMENTS WHEN APPARENT): The beaker has three horizontal sets of three or four fine-line horizontal engraved lines, two of the sets dividing horizontal engraved panels with intricate engraved elements (Figure 7). Each of the two engraved panels have upper and lower curvilinear scrolls and surrounding upper and lower curvilinear lines repeated four times across each panel, and the scrolls meet at a central excised circle. The curvilinear scroll elements are divided by a series of three or four diagonal engraved lines. Portions of the engraved scrolls and diagonal engraved lines have been pronounced through the use of excised areas.

PIGMENT USE AND LOCATION ON VESSEL: white pigment in the engraved lines

TYPE AND VARIETY (IF KNOWN): Spiro Engraved

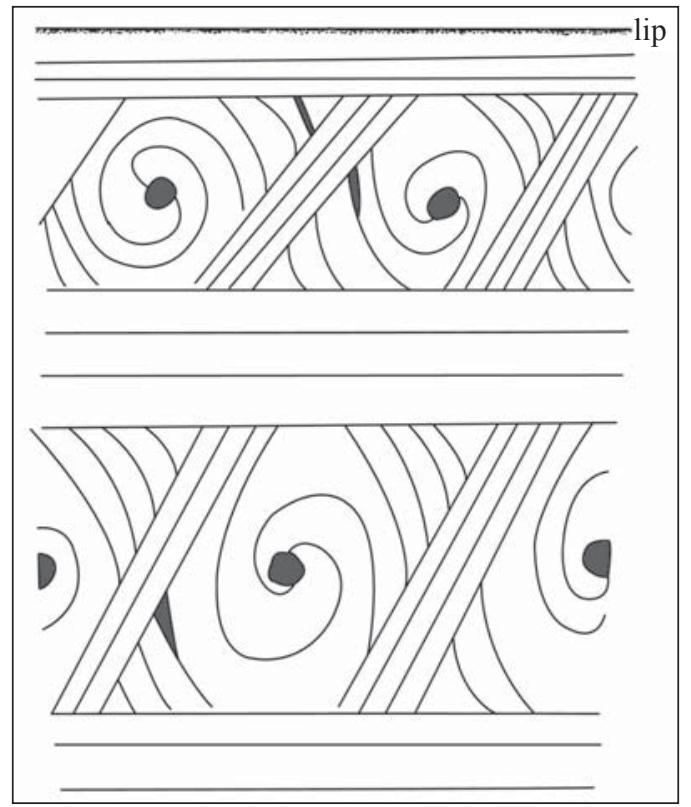

Figure 7. Spiro Engraved beaker from the Boxed Spring site. 
SITE NAME OR SITE NUMBER: Boxed Spring

VESSEL NO.: 1-5

VESSEL FORM: Carinated bowl

NON-PLASTICS AND PASTE: grog

RIM AND LIP FORM: Direct rim and rounded lip

CORE COLOR: $\mathrm{G}$ (fired in a reducing environment and cooled in the open air)

INTERIOR SURFACE COLOR: dark grayish-brown; fire clouds on the rim

EXTERIOR SURFACE COLOR: reddish-brown; fire clouds on the rim, body, and base

WALL THICKNESS (IN MM): rim, $6.2 \mathrm{~mm}$; body, $6.4 \mathrm{~mm}$; base, $7.0 \mathrm{~mm}$

INTERIOR SURFACE TREATMENT: smoothed

EXTERIOR SURFACE TREATMENT: burnished

HEIGHT (IN CM): 8.9

ORIFICE DIAMETER (IN CM): 21.4

DIAMETER AT BOTTOM OF RIM OR NECK (IN CM): N/A

BASE DIAMETER (IN CM) AND SHAPE OF BASE: N/A

ESTIMATED VOLUME (IN LITERS): 1.15 liters

DECORATION (INCLUDING MOTIF AND ELEMENTS WHEN APPARENT): Plain

PIGMENT USE AND LOCATION ON VESSEL: None

TYPE AND VARIETY (IF KNOWN): Unidentified plain ware

SITE NAME OR SITE NUMBER: Boxed Spring

VESSEL NO.: 1-6

VESSEL FORM: Beaker

NON-PLASTICS AND PASTE: fine grog

RIM AND LIP FORM: Direct rim and rounded lip

CORE COLOR: B (fired and cooled in a reducing environment)

INTERIOR SURFACE COLOR: very dark grayish-brown 
EXTERIOR SURFACE COLOR: very dark grayish-brown; fire clouds on the rim and body

WALL THICKNESS (IN MM): rim, $2.9 \mathrm{~mm}$; body, $3.5 \mathrm{~mm}$

INTERIOR SURFACE TREATMENT: smoothed

EXTERIOR SURFACE TREATMENT: burnished

HEIGHT (IN CM): 11.5

ORIFICE DIAMETER (IN CM): 9.9

DIAMETER AT BOTTOM OF RIM OR NECK (IN CM): N/A

BASE DIAMETER (IN CM) AND SHAPE OF BASE: 8.5; circular and rounded

ESTIMATED VOLUME (IN LITERS): 0.69 liters

DECORATION (INCLUDING MOTIF AND ELEMENTS WHEN APPARENT): Plain

PIGMENT USE AND LOCATION ON VESSEL: None

TYPE AND VARIETY (IF KNOWN): Unidentified plain ware (Boxed Spring Plain)

SITE NAME OR SITE NUMBER: Boxed Spring

VESSEL NO.: 1-7

VESSEL FORM: Beaker

NON-PLASTICS AND PASTE: fine grog

RIM AND LIP FORM: Direct rim and rounded, thinned, lip

CORE COLOR: B (fired and cooled in a reducing environment)

INTERIOR SURFACE COLOR: grayish-brown

EXTERIOR SURFACE COLOR: grayish-brown; fire clouds on the rim, body, and the base

WALL THICKNESS (IN MM): rim, $2.7 \mathrm{~mm}$; body, $3.3 \mathrm{~mm}$; base, $3.2 \mathrm{~mm}$

INTERIOR SURFACE TREATMENT: burnished on the rim and smoothed on the body

EXTERIOR SURFACE TREATMENT: burnished

HEIGHT (IN CM): 12.0

ORIFICE DIAMETER (IN CM): 9.6

DIAMETER AT BOTTOM OF RIM OR NECK (IN CM): N/A 
BASE DIAMETER (IN CM) AND SHAPE OF BASE: 8.8; circular and convex ESTIMATED VOLUME (IN LITERS): 0.69 liters

DECORATION (INCLUDING MOTIF AND ELEMENTS WHEN APPARENT): Plain PIGMENT USE AND LOCATION ON VESSEL: None TYPE AND VARIETY (IF KNOWN): Unidentified plain ware (Boxed Spring Plain)

SITE NAME OR SITE NUMBER: Boxed Spring

VESSEL NO.: 1-8

VESSEL FORM: Beaker

NON-PLASTICS AND PASTE: fine grog

RIM AND LIP FORM: Direct rim and rounded lip

CORE COLOR: B (fired and cooled in a reducing environment)

INTERIOR SURFACE COLOR: very dark grayish-brown

EXTERIOR SURFACE COLOR: very dark grayish-brown; fire clouds on the rim and body

WALL THICKNESS (IN MM): rim, $3.8 \mathrm{~mm}$; body, $3.8 \mathrm{~mm}$

INTERIOR SURFACE TREATMENT: smoothed

EXTERIOR SURFACE TREATMENT: burnished

HEIGHT (IN CM): 12.3

ORIFICE DIAMETER (IN CM): 9.8

DIAMETER AT BOTTOM OF RIM OR NECK (IN CM): N/A

BASE DIAMETER (IN CM) AND SHAPE OF BASE: 9.2; circular and rounded

ESTIMATED VOLUME (IN LITERS): 0.72 liters

DECORATION (INCLUDING MOTIF AND ELEMENTS WHEN APPARENT): Plain PIGMENT USE AND LOCATION ON VESSEL: None

TYPE AND VARIETY (IF KNOWN): Unidentified plain ware (Boxed Spring Plain) 


\section{SUMMARY AND CONCLUSIONS}

Excavations in 1962 of one of the ancestral Caddo mounds at the Early Caddo period Boxed Spring site (41UR30) uncovered a large tomb (Burial 2) with multiple individuals. Among the funerary offerings placed with these individuals were eight ceramic vessels that we have documented in this article; these vessels were subsequently donated to the Texas Archeological Research Laboratory at The University of Texas at Austin in 1986.

The vessels include two plain bottles, a plain carinated bowl, three plain beakers (Boxed Springs Plain), a Hollyknowe Ridged jar, and a Spiro Engraved beaker; the common occurrence of beakers in Burial 2 is notable. Similar beakers of the Holly Fine Engraved and Spiro Engraved types have been recovered from the Crenshaw and Spiro sites in Southwest Arkansas and eastern Oklahoma, respectively (see Suhm and Jelks 1962:Plates 40f and 74i). Other engraved beakers of the Hickory Engraved, Holly Fine Engraved, and Spiro Engraved types have been recovered from burials in the large community cemetery at the Boxed Spring site (Perttula 2011:Figures A4.88, A4.93, and A4.104-105), along with one plain beaker (Perttula 2011:Figure A4.110).

The beakers from Burial 2 at the Boxed Spring site were manufactured by master Caddo potters, with either exquisite fine line decoration or well-prepared vessel formation. The rims on the four beakers range from only 2.7-3.9 $\mathrm{mm}$ in thickness and body thickness ranges from only 3.3-3.8 $\mathrm{mm}$. We suspect that these vessels were manufactured for a special purpose, likely to hold unknown and uncommon liquid concoctions.

\section{ACKNOWLEDGMENTS}

We thank Mary Beth Tomka and Jonathan Jarvis of the Texas Archeological Research Laboratory at The University of Texas at Austin and Robert Cast of the Caddo Nation of Oklahoma for access to the Boxed Spring site vessel collections. Lance Trask prepared the figures in this article.

\section{REFERENCES CITED}

Perttula, T. K.

2011 (assembler) Archaeological and Archaeogeophysical Investigations at an Early Caddo Mound Center in the Sabine River Basin of East Texas, Special Publication No. 15. Friends of Northeast Texas Archaeology, Austin and Pittsburg.

Perttula, T. K. and D. E. Wilson, with contributions by M. Walters

2000 An Early Caddoan Period Cremation from the Boxed Springs Mound Site (41UR30) in Upshur County, Texas, and a Report on Previous Archaeological Investigations. Journal of Northeast Texas Archaeology 12:31-71.

Suhm, D. A. and E. B. Jelks (editors)

1962 Handbook of Texas Archeology: Type Descriptions. Special Publication No. 1, Texas Archeological Society, and Bulletin No. 4, Texas Memorial Museum, Austin. Reprinted in 2009, Gustav's Library, Davenport, Iowa. 